\title{
The Effectiveness of 5E Learning Cycle Accompanied by Mind Mapping on Creative Thinking
}

\author{
Dhani Nugrahaningtyas Utami ${ }^{1}$, Bambang Subali ${ }^{2}$ \\ \{dhaniutami@gmail.com¹, bambangsubali@uny.ac.id ${ }^{2}$ \} \\ ${ }^{1}$ Biology Education, Graduate School Universitas Negeri Yogyakarta, Jl. Colombo No.1, Indonesia \\ ${ }^{2}$ Faculty of Mathematics and Natural Sciences Universitas Negeri Yogyakarta, J1. Colombo No.1, \\ Indonesia
}

\begin{abstract}
The development of technology and information in the $21^{\text {st }}$ century raises the problems that need to be solved by creative thinking ability. As a result, it is needed the learning that can support the students to increase their ability to think creatively. This research aims to find out the effectiveness of $5 \mathrm{E}$ learning cycle model accompanied by mind mapping on creative thinking ability. This research used quantitative research with quasi experimental design. The data collecting technique was test in form of essay to measure the aspects of fluency, flexibility, and originality. Based on the results of the independent $t$-test analysis, the significance was $0,001<0,05$. As for the $N$ Gain value of the experiment class was 0,70 with high criteria and the control class was 0,57 with moderate criteria. Thus, it can be concluded that $5 \mathrm{E}$ learning cycle model with mind mapping is effective to increase creative thinking ability.
\end{abstract}

Keywords: Effectiveness, 5E Learning Cycle, Mind Mapping, Creative Thinking

\section{Introduction}

Rapid development of technology and information in the $21^{\text {st }}$ century creates complexity and uncertainty in various areas, such as economic and social (Shum dan Crick, 2016)[13]. All efforts to meet the needs of life in $21^{\text {st }}$ century in the fields of education, economics, and industry are now based on knowledge (knowledge age). Knowledege is the main capital to face the occurance of a period shift from the industrial age to knowledge age. Knowledge is a solution in creating high quality human resources who are ready to face the knowledge age in the $21^{\text {st }}$ century (Wijaya, Sudjimat, dan Nyoto, 2016)[16]. Education that is said to be successful today is education that can expand and apply to new situations that have never been encountered before in real life. That is education that involves thinking abilities such as creative and critical thinking in solving problems, communicating and collaborating abilities and not merely obtaining knowledge (content knowledge) (Schleicher, 2011) [12], (Marope, 2014) [8]. From those various competencies that are necessary to have in the $21^{\text {st }}$ century, the ability to think creatively is a competency that needs to be had in the $21^{\text {st }}$ century. It is because creative thinking allows a person to be flexible to various conditions that may occur as a result of the rapid development of the age (Ritter dan Mostert, 2016)[9].

The process of creative thinking will produce creativity. Creativity is the ability to create new ideas by combaining and manipulating the knowledge. It is important to use creativity to solve various problems (Wong \& Siu, 2012)[17]. However, based on the survey results by Martin Posperity of 139 countries on Global Creativity Index (GCI), Indonesia ranks 115th. These results indicate that Indonesia's creativity is still low. This happens because schools in 
Indonesia have not yet developed the ability to think creatively. Based on the interview results in SMAN 1 Pundong, learning has not yet focused on mastering creative thinking abilities. The problems given in learning have not been linked to the real problems which are encountered by students in their daily life. As a result, students' creative thinking abilties are still low. Alternative solution offered to overcome these problems is by using the $5 \mathrm{E}$ learning cycle model.

$5 \mathrm{E}$ learning cycle model is a learning model that is based on constructivism approach, student-centered, and has five steps: engage, explore, explain, elaborate, and evaluate (Lederman, 2010) [6]. 5E learning cycle model facilitates students to develop concepts which are used to solve problems (Hardiyasa, Suma, \& Sadia, 2014)[4]. In addition, it enables students to know more about the real world and help them to analyze and synthesize the information obtained so students can develop their ability to solve problems (Yaman \& Karaşah, 2018)[18]. In line with those opinions, the steps of 5E learning cycle model allow students to examine and test the materials, then find and build concepts based on the results of the test and apply that concept to new ideas (Salameh Al Majali, 2013)[11]. Those ideas will be used as solution to solve the problems, so that the teacher plays a major role in stimulating students to emit the ability to think creatively to produce diverse ideas. The effort that teachers can make to help students create ideas is by combining $5 \mathrm{E}$ learning cycle model with mind mapping.

Mind Mapping is a note taking technique that uses visual and non-linear thinking processes and this techique is developed by Tony Buzan (Royal, 2010)[10]. Mind mapping consists of interconnected networks and aims to find creative associations of various ideas or concepts (Davies, 2011)[1]. Mind mapping helps students to organize the information, ideas, and thoughts and then solve problems (Mandal, 2014)[7]. Accordingly, in this paper, the researchers intend to conduct the research on the effectiveness of $5 \mathrm{E}$ learning cycle model with mind mapping on creative thinking ability.

\section{Method}

\subsection{Type and Design of Research}

This research used quantitative research with quasi experimental design. The quasi experimental design used was nonequivalent control group design. This research used experimental group and control group. Experimental group was given the treatment of 5E learning cycle model with mind mapping. Meanwhile, control group was given the treatment of $5 \mathrm{E}$ learning cycle model.

\subsection{Population and Sample}

This research was conducted in SMA Negeri 1 Pundong, Bantul Regency, Yogyakarta in Februari to March 2019. The research population was all students of class XI IPA in SMA Negeri 1 Pundong and the target population was the population that have characteristic such as population research. The research samples were students of class XI IPA 1 as an experimental group and students of class XI IPA 2 as a control group with each class totaling 32 students. The research samples were taken by using cluster random sampling. 


\subsection{Data Collection Techniques and Instruments}

The technique of collection data was test. The instrument test used were essay test which arranged to measure the ability to think creatively at the cognitive level of analyzing (C4) and evaluating (C5) the material of excretory system. The scoring test of creative thinking ability refers to Diakidoy (Kind \& Kind, 2008: 16)[5] which assesses the aspect of fluency, flexibility, and originality.

\subsection{Data Analysis Technique}

The results of pre test and post test were analyzed by parametric prerequisite tests in the form of normality and homogeneity test with SPSS vesion 17,0 for windows. Normality test was conducted to find out whether the data was normally distributed or not. Meanwhile, homogeneity test was conducted to find out that the two samples used were from population that had the same variations. After the analyzed data fulfilled the parametric requirements, then the hypothesis test was carried out, namely independent t-test. Pre test and post test data were also measured to increase the ability to think creatively using N-gain in order to find out the effectiveness of the two treatments used. The formula of $\mathrm{N}$-gain proposed by Hake (1999)[3] is as follows:

$$
g=\frac{\text { postest score }- \text { pretest score }}{\text { maximum score }(100)-\text { pretest score }}
$$

Next, N-gain result was interpreted according to the criteria in the following table:

Table 1. N-Gain criteria

\begin{tabular}{cl}
\hline N-Gain value & Classification \\
\hline $\mathrm{g}<0,3$ & Low \\
$0,3 \leq \mathrm{g}<0,7$ & Medium \\
$\mathrm{g} \geq 0,7$ & High \\
\hline
\end{tabular}

\section{Result}

Based on the results of the research, it was obtained the descriptive analysis of pre test and post test of the ability to think creatively in experimental and control group, as presented in table 2. Based on the data, the average pre test score of experimental and control group were 16,27 and 14,58. It showed that the initial students' ability of think creatively before got the treatments in the experimental and control group were not significantly different. After getting the treatments, there were differences in the average score of experimental and control group. As for the average score of the experimental and control group were 76,43 and 62,50.

Table 2. The Description of Creative Thinking Ability of the Experimental and Control Group

\begin{tabular}{|c|c|c|c|c|}
\hline \multirow{3}{*}{ Description } & \multicolumn{4}{|c|}{ Group } \\
\hline & $\begin{array}{r}\text { Exper } \\
\text { learning } \\
\text { Mind }\end{array}$ & $\begin{array}{l}\operatorname{al}(5 E \\
\text { model+ } \\
\text { ping) }\end{array}$ & $\begin{array}{r}\text { Contro } \\
\text { cy }\end{array}$ & $\begin{array}{l}\text { learning } \\
\text { odel) }\end{array}$ \\
\hline & Pre test & Post test & Pre test & Post test \\
\hline
\end{tabular}




\begin{tabular}{ccccc}
\hline Average Score & 16,27 & 76,43 & 14,58 & 62,50 \\
Minimum Score & 4,17 & 45,83 & 0,00 & 37,50 \\
Maximum Score & 33,33 & 100 & 33,33 & 91,67 \\
Standard Deviation & 8,48 & 16,78 & 9,34 & 13,87 \\
\hline
\end{tabular}

Based on the data in table 3 , it showed that the significance value of the pre test in the experimental group was 0,200 and control group was 0,062 . The significance value of pre test score in both groups showed a higher value than $\alpha$ value $(0,05)$. This showed that both groups were normally distributed. After the treatments, the normality test was carried out on post test result, the result of normality test was presented in table 3 . The result of normality test on post test showed that experimental group had significance value of 0,200 and control group was 0,130 . The two significance values were higher than $\alpha$ value $(0,05)$. This showed that both groups were normally distributed.

Table 3. The Results of Normality Test on Creative Thinking Ability

\begin{tabular}{cccc}
\hline \multirow{2}{*}{ Intervention } & \multicolumn{2}{c}{ Kolmogorov-Smirnov $^{\mathbf{a}}$} \\
\cline { 3 - 4 } Pre test & Experimental group & Df & Sig. \\
\multirow{2}{*}{ Post test } & Control group & 32 & 0,200 \\
& Experimental group & 32 & 0,062 \\
& Control group & 32 & 0,200 \\
& & & 0,130 \\
\hline
\end{tabular}

Based on the results of the homogeneity test presented in table 4 , it showed that pre test and post test score had a higher significance value than $\alpha$ value $(0,05)$. As for each pre test significance value was $0,634>0,05$ and post test significance value was $0,129>0,05$. This showed that pre test and post test variance in each group of experimental and control group were homogeneous.

Table 4. The Results of Homogeneity Test on Creative Thinking Ability

\begin{tabular}{ccccc}
\hline & Levene Statistic & df1 & df2 & Sig. \\
\hline Pre test & 0,229 & 1 & 62 & 0,634 \\
Post test & 2,371 & 1 & 62 & 0,129 \\
\hline
\end{tabular}

Based on the results of independent t-test as presented in table 5 , the significance value of pre test was higher that $\alpha$ value $(0,05)$, that was $0,451>0,05$. It showed that Ho was accepted which means there was no significant difference between the average score of experimental group which used $5 \mathrm{E}$ learning cycle model with mind mapping and control class which used $5 \mathrm{E}$ learning cycle model. Meanwhile, the significance value of post test showed that it was lower than $\alpha$ value $(0,05)$, that was $0,001<0,05$. It means Ha was accepted or there was significant difference between the average score of experimental group which used $5 \mathrm{E}$ learning cycle model with mind mapping and control group which used 5E learning cycle model.

Table 5. The Results of Independent t-test on Creative Thinking Ability

\begin{tabular}{|c|c|c|c|c|}
\hline Data Type & Sig. (2-tailed) & $\alpha$ & Decision & Inference \\
\hline Pre test & 0,451 & 0,05 & Ho is accepted & $\begin{array}{c}\text { There is no significant } \\
\text { difference }\end{array}$ \\
\hline Post test & 0,001 & 0,05 & Ha is accepted & There is significant \\
\hline
\end{tabular}


Based on the results of the analysis of N-Gain as presented in Figure 1, it was known that $\mathrm{N}$-Gain value of experimental group was higher than control group. Experimental group which used 5E learning cycle model with mind mapping had N-Gain of 0,70 which categorized as high whereas control group which used $5 \mathrm{E}$ learning cycle model had N-Gain of 0,57 which categorized as medium.

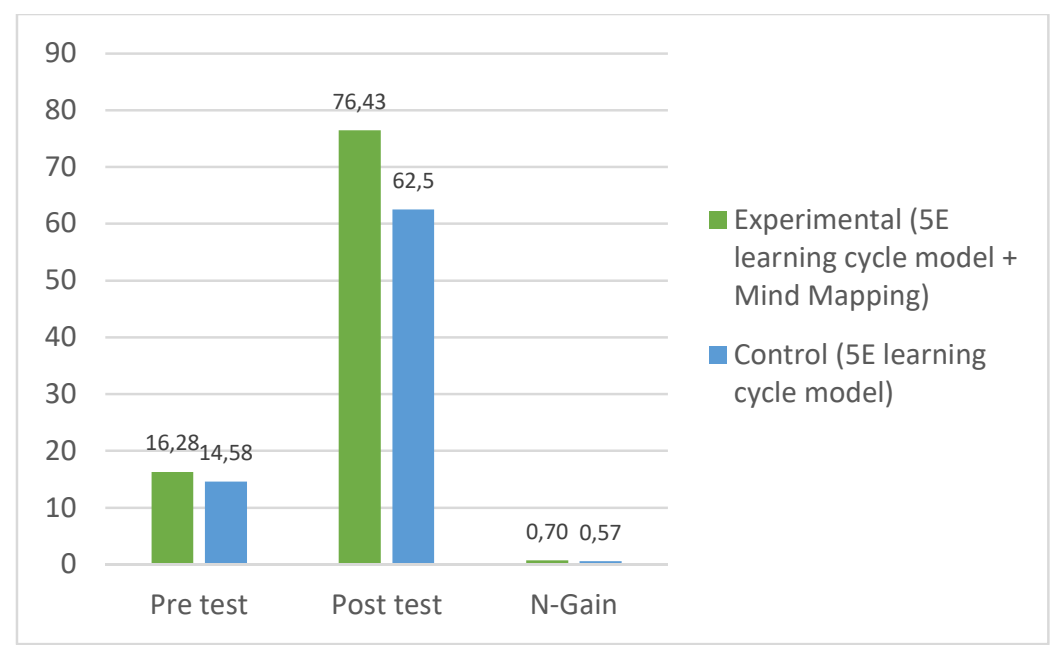

Fig. 1.The Diagram of Pre test, Post test, and N-Gain of Creative Thinking Ability

\section{Discussion}

Learning by applying $5 \mathrm{E}$ learning cycle model accompanied by mind mapping is effective in increasing creative thinking ability in excretory system material. It is proven by the result of independent t-test which shows that significance value is lower than $\alpha$ value, that is $0,001<$ 0,05 . It means that there is a difference in the average score of students' creative thinking ability between the students who are given the treatment of $5 \mathrm{E}$ learning cycle model with mind mapping and 5E learning cycle model. The average score of experimental group after being given the treatment is 76,43 while the average score of control group after being given the treatment is 62,50 . Based on the analysis of N-Gain, experimental group gets 0,70 which categorized as high and control group gets 0,57 which categorized as medium.

$5 \mathrm{E}$ learning cycle model with mind mapping is effective to increase creative thinking ability because of its steps which facilitate students to express their ideas/thoughts based on the knowledge they have to solve problems. This learning model stimulates students to be active to build their own knowledge. The questions are given at the beginning of learning which is called engage stage. Then in the explore stage, students explore the concept based on the topic being discussed in groups. The interactions which occur while discussing in groups give students the chance to share ideas and experiences to solve problems, so that it increases their ability to think creative. Discussion activities train students to think fluently, flexibly, and originally (Yuliawati \& Panjaitan, 2017)[19]. Next, students explain the concepts and ideas they have got by using their own language in the explain stage. Then, the concepts that 
have been obtained are expanded by applying the concepts to new situations or different problems at the elaborate stage. The elaborate stage can improve the ability to think creatively on aspects of fluency, flexibility, and originality. The problem will stimulate students to think of many ideas (fluency), try to find the right solution (flexibility) and generate new ideas (originality). Students are asked to apply the obtained concept to new situations by making mind map. The problems which have to be done become the theme in mind map. Then, each students gives ideas of the problem by making branches completed with pictures, colors, and letters. Mind map helps students to remember, organize and associate the concepts they have with their problems. This process triggers students to think creatively. In line with the research results, Tee, et al. (2014)[15] state that mind mapping helps students to remember all of the information given and increase the ability to think creatively. At the end of learning which is called evaluate stage, the knowledge obtained is evaluated to find out the extent to which students get knowledge.

Learning by applying $5 \mathrm{E}$ learning cycle model can increase creative thinking ability. This result is in line with the previous studies. Based on the study conducted by Hardiyasa et al. (2014)[4], 5E learning cycle model increases the creative thinking ability because this model uses constructivism approach proposed by Piaget. According to the study conducted by Soon, Meng, \& Jong (2017)[14], 5E learning cycle model enhances the aspect of creative thinking, namely the aspect of flexibility in producing various solutions conceptually. Students apply the knowledge obtained to various situations, so through that process students' creative thinking ability in solving problems can develop. Solving new problem is easier to obtain by connecting various concepts which have been obtained. Mind mapping technique improves the ability to think creatively. These results are also in line with the study proposed by Fatmawati (2016)[2] which shows that mind mapping helps students in expressing ideas fluently, flexibly, and originally.

\section{Conclusion}

$5 \mathrm{E}$ learning cycle model accompanied by mind mapping is effective to increase the creative thinking ability of eleventh grade students in SMA Negeri 1 Pundong. This result is proven by the results of independent t-test analysis which show that significance value is lower than $\alpha$ value $(0,001<0,05)$. There is improvement of creative thinking ability in both groups of experimental and control group which showed by $\mathrm{N}$-Gain scores. Experimental group which uses $5 \mathrm{E}$ learning cycle model with mind mapping has $\mathrm{N}-$ Gain of 0,70 which is categorized as high. Meanwhile, control group which uses 5E learning cycle model has NGain of 0,57 which is categorized as medium.

\section{References}

[1] Davies, M. : Concept mapping, mind mapping and argument mapping: what are the differences and do they matter? High Education, 62, 279-301. https://doi.org/10.1007/s10734-010-9387-6 (2011)

[2] Fatmawati, B. : The analysis of students' creative thinking ability using mind map in biotechnology course. Jurnal Pendidikan IPA Indonesia, 5(2), pp 216-221. https://doi.org/10.15294/jpii.v5i2.5825 (2016)

[3] Hake, R. : Analyzing Change/Gain scores (1999)

[4] Hardiyasa, I., Suma, K., \& Sadia, I. : Pengaruh Model Siklus Belajar 5E terhadap Keterampilan Berpikir Kreatif dan Motivasi Berprestasi Siswa. E-Journal Program Pascasarjana Universitas Pendidikan Ganesha, 4. Retrieved from 
http://119.252.161.254/e-journal/index.php/jurnal_ipa/article/download/1064/812

(2014)

[5] Kind, P. M., \& Kind, V. : Creativity in science education: Perspectives and challenges for developing school science. Studies in Science Education, 43(1), 37. https://doi.org/10.1080/03057260708560225 (2008)

[6] Lederman, S. : Levels of Inquiry and the 5 E's Learning Cycle Model. (2010)

[7] Mandal, H. K. : Brainstorming Approach And Mind Mapping In Synergy Creating Activity. Global Journal of Finance and Management, 6(4), pp 333-338 (2014)

[8] Marope, P. T. M.. : Learning and competences for the 21st century. Prospects, 44(4), pp 483-486. https://doi.org/10.1007/s11125-014-9333-y (2014)

[9] Ritter, S. M., \& Mostert, N. : Enhancement of Creative Thinking Skills Using a Cognitive-Based Creativity Training. Journal of Cognitive Enhancement, 1(3), pp 243253. https://doi.org/10.1007/s41465-016-0002-3 (2016)

[10] Royal, B. :The Little Blue Reasoning Book 50 Powerful Principles For Clear And Effective Thinking. Canada: Maven Publishing (2010)

[11] Salameh Al Majali, Y. D. : The impact of (5Es) learning cycle on the outcome and the development of creative thinking among students of seventh grade in Arabic language course in Alqaser/Karak Brigade. International Journal of Academic Research, 5(5), pp 31-40. https://doi.org/10.7813/2075-4124.2013/5-5/B.5 (2013)

[12] Schleicher, A. : The case for 21st century learning. Organisation for Economic Cooperation and Development. The OECD Observer, (282/283), 42 (2011)

[13] Shum, S. B., \& Crick, R. D. : Learning Analytics for 21st Century Competencies. Journal of Learning Analytics, 3(2), 6-21. https://doi.org/S0167-4781(97)00063-8 [pii] (2016)

[14] Soon, L. C., Meng, C. C., \& Jong, Y. O. : Learning Mathematical Flexibility in a Constructivist 5E Model Low Chee Soon*. International Conference on Language, Literaure, Culture and Education, pp 1-14 (2017)

[15] Tee, T., et al. : Buzan Mind Mapping: An Efficient Technique for. International Journal of Social, Behavioral, Educational, Economic, Business and Industrial Engineering, 8(1), 28-31 (2014)

[16] Wijaya, E. Y., Sudjimat, D. A., \& Nyoto, A. : Transformasi Pendidikan Abad 21 Sebagai Tuntutan. Jurnal Pendidikan, 1, pp 263-278 (2016)

[17] Wong, Y. L., \& Siu, K. W. M. : A model of creative design process for fostering creativity of students in design education. International Journal of Technology and Design Education, 22(4), pp 437-450. https://doi.org/10.1007/s10798-011-9162-8 (2011)

[18] Yaman, S., \& Karaşah, Ş. : Effects Of Learning Cycle Models On Science Success : A Meta-Analysis. Journal of Baltic Science Education, 17(1), pp 65-83 (2018)

[19] Yuliawati, N., \& Panjaitan, R. L. : Pengaruh Discovery Learning Terhadap Kemampuan Berpikir Kreatif Siswa Sekolah Dasar. Pena Ilmiah, 2(1), pp 221-230 (2017) 